\section{BEYOND THE COCKFIGHT: MASCULINITY AND THE THAI DOVE-COOING CONTEST}

\section{Wanni Wibulswasdi Anderson ${ }^{1}$}

\section{Abstract}

The Dove-cooing contest in Thailand began as a leisure activity, the hobby of a particular group of men who found peace, pleasure, and enjoyment in listening to the songs of the singing doves. Some hoped for good luck in raising doves with propitious characteristics. The hobby developed into a sport through the initiative of the Association of Dove Breeders in Thailand. The Association's encouragement of dove breeding found enthusiastic support from dove lovers in all regions, especially in Southern Thailand where many prize-winning doves came from. The study presents the training and care of doves, selected scenes of the contest, the rules by which the singing doves are judged, and analyzes multiple structural and ideational dynamics involved in the event. Not simply a folk sport, an animal sport in and of itself, the dove-cooing contest is about the dove fancier. But it also transcends the individual. In its national, societal context, the people who organize and participate in the event are more socially and ethnically diverse, more socially aware, and more engaged in the needs of the community. The contest facilitates boundary-crossings: ethnic, social, economic, regional, and international - as diverse groups of dove

\footnotetext{
${ }^{1}$ Professor, Department of Anthropology and Ethnic Studies Concentration, Brown University
}

fanciers enter their prized doves into the arena and hope to be a winner. It is a "deeper play" in the Geertzian sense.

\section{Introduction}

"Goog-groo gog gog! Goog-groo gog gog!" This is how the Thai novel, Golden Necklace (Soi Tong), begins. The novel is an acclaimed work by a village school headmaster in Sukhothai, Nimit Phumetaworn, an award winner for Thai literature in 1976. The sound heard at the beginning of the novel is that of a dove cooing. It is a domesticated dove whose owner Loy has named Golden Necklace.

The song soars clear and low, to Loy's delight.

Loy snaps his fingers and makes vocal sounds, his response to the dove's cooing. He walks over to the cage of Golden Necklace, his favorite songbird. Bobbing his head up and down, clever Golden Necklace continues to coo. He struts around the cage, occasionally thrusting his head between the wooden slats of the cage to show off the shining pattern of black, white, and brown circling his neck like a necklace that has been painted on by an artist. His eyes, round and clear, sparkle like clear drops of water.

Golden Necklace is Loy's friend, his consolation for his loneliness and anxiety. Loy loves Golden Necklace as if he were a son - his second son, next to his only son Ruay. Golden Necklace never fails to please Loy with his cooing of welcome when he sees Loy step up into the house. And 
whenever Loy returns home late from his rice paddy, he finds Golden Necklace cooing excitedly in a quick tempo and running around the cage happily at the sight of Loy. Playfully he pecks Loy's hand. Had there been no slats on the cage, he probably would have embraced Loy.

To buyers interested in Golden Necklace, Loy responds, "Even though I'm dirt poor, I'd never sell him. Not even for an ox-cart full of rice!"

Loy looks after Golden Necklace better than he looks after himself. He handcrafted the beautiful cage for Golden Necklace himself. With his sharp knife, he smoothes the bamboo slats and smokes them to give them a beautiful golden shine. He binds the slats together with rattan strips. To make sure there is enough food for Golden Necklace the whole year round, he grows makoe grass, rice, and maize

(Phumetaworn 2525:1-2)

Phumetaworn skillfully crafts a representation of the close bond between a pet dove and his owner in Thai culture. The integration of this Thai animal sport and hobby into the realm of literary representation makes his novel a rare treat to folklorists. The bonding between man and animal encapsulates many of the basic tenets in Thai culture and depicts Thai individuals like the protagonist Loy as agencies of their own life choices, negotiations, likes and dislikes, and how they see themselves in relation to others.

I shall trace the evolution of the Thai hobby of raising doves, from being avian pets into the contemporary sport of the dove-cooing contest, the fastest growing folk sport in Thailand, and how the traditional Thai value system continues to inform and shape contemporary Thai ways of life and behaviors.

The dove-cooing contest can be best understood as a development of multiple meanings within a complex of activities analyzed here on several levels. The analysis discusses dove cooing as a process, the sport as an outgrowth of a historical development of men's hobby, as a cultural behavior associated with a certain constellation of personality characteristics, and as a milieu for creating interactional networks crosscutting multiple social boundaries and nation-state territories. By tracing the history of the evolution of the dove-cooing contest, its popularity, and why so many Thais are enamored with this sport, I further intend to shed some light on the interconnection between dove-raising as a hobby, the Thai world view of birds in their natural habitat, and, as most dove-raisers are men, the Thai concept of masculinity.

\section{Raising Doves as a Hobby}

The hobby of keeping and raising doves as pets in the region which is now Thailand dates at least back to the period of the Khmer political dominance of the area. Bas-reliefs in two Cambodian stone temples, Phanom Rung Temple in Buriram and Phimai Temple in Koraj, depict a village scene of houses on stilts, with grass roofs and bamboo dove cages hanging from the eves. It is assumed that dove-raising was most likely also practiced later on during the Ayudhya period, but due to the destruction of written documents after Ayudhya was sacked by the Burmese, no written record exists to verify it. Through time, dove-raising has developed to become a science of its own. During the last two centuries of the present Chakri Dynasty, two 
kings, King Nagklao (1824 -1851) and King Chomklao (1851-1868), ordered a compilation of existing data on doves from dove experts. King Chomklao wrote a treatise on doves in poetic form himself (Wannaprasert 2528a: 4069, Kananurak 2531 4-24) thereby elevating the prestige of dove-raising as a hobby through such royal endorsement. "A dove that sings 'gu ru pong' is as valuable as a diamond," King Rama IV wrote. The final long note of the dove song, vocalized either as "pong, gong, or wong" are vocal markers of good singing doves (Wannaprasert 2528a: 9). King Chomklao's view is shared by contemporary dove lovers. Wannaprasert, a contemporary author of books on doves, ranks dove-raising as a hobby higher than raising orchids, a hobby of many Thai men. He justifies his ranking, claiming "A good singing dove is rarer and harder to find than a beautiful orchid" (Wannprasart 2528a:8). "A gift of a good singing dove is a precious gift and a 'debt of gratitude' that is always remembered by the receiver," said another dove fancier (Wichai Tantisatjaphirat, personal communication, 2530). Dr. Prasop Rattanakorn, a well-known Thai psychiatrist, sees its merits from the mental health perspective. "The singing of the doves is an excellent therapy for mental patients. A family that raises doves as pets will never see a mentally ill person," Dr. Rattanakorn proclaimed (Laosat 2526:79). The therapeutic value of pets has been similarly avocated by American psychiatrists. Many states in America have a program in which dogs and cats are occasionally taken to homes for senior citizens to give the elderly the pleasure of petting them and hearing the happy purring of cats.
The royal treatise imparts numerous meanings to doves. Some doves were praised for the aesthetic quality of their songs. Others were coveted for certain physical markers- shape, coloration, and markings - that were considered auspicious. Luck-giving doves, such as a white dove, a dove with a necklace around its neck, with yellow rings around its eyes, or a dove with 13-15 tail feathers, were believed to bring owners their high position, status, prosperity and happiness, and even protection from danger. The treatise lists 59 propitious characteristics and 19 unpropitious characteristics in doves (Wannaprasert 2528b:115). There appears to exist in the Thai dove taxonomy then, two recognized categories by which men selected doves to raise. In the first category are doves raised for their physical characteristics, associated with popular religion and with eliciting positive instrumental benefits. In the second category are doves raised for their beautiful singing voices, associated with eliciting positive aesthetic appreciation and pleasure.

Until recently, both luck-giving doves and singing doves were trapped from the wild. Loy, the protagonist in the novel mentioned above, pursues his hobby by spending days and days in the forest, tracking and luring the coveted dove. Given the difficulties of obtaining doves under these circumstances, it is difficult to know if both types were equally sought after. In contemporary dove-raising circles where, since 1971, most doves are bred in captivity (Wannaprasert 2528b:131), most doves are sought for their melodious singing voices. This in itself is noteworthy. For contemporary dove fanciers, clearly the perceived aesthetic quality of doves outshines their potential luck-giving qualities, and it is 
this attribute that forms the core of the dovecooing contest.

Thai bird connoisseurs regard doves as surpassing all other songsters in the birdworld in terms of the melodic beauty of their songs. Within this special group of dove fanciers, 2 sub-species of doves are specifically raised and pampered: nok kao yai (large sized dove), also referred to as the spotted-necked dove, Streptopelia chinensis spp. (Lekagul and Cronin Jr. 1974:92) and nok kao lek (small-sized dove), identified as the barred ground-dove or the merbok, commonly referred to in Thailand as the Javanese dove or the zebra dove, Geopelia striata spp. (Lekagul and Cronin Jr 1974:92). To the discerning ears of dove fanciers, the songs of the barred ground dove with its lilting continuity of notes are more melodious than those of the large-sized dove (Dej Petkhaeg, Thai Muslim dove-raiser on Koh Klang, personal communication, 1987). The Barred Ground Dove Association of Thailand was established in 1966. As of 1984, there were 33 regional associations in 33 provinces out of 72 provinces in Thailand, with about 100, 000 Thai men said to raise doves as their hobby (Wannaprasert 2528b: 5).

\section{Dove-cooing Contest as a Sport}

Animal sports have long been a significant aspect of the Thai leisure tradition. Rounding up wild elephants, for example, was a royal sport as well as a means of obtaining war animals for battle. Elephant battles and battles between elephants and a tigers were staged in Ayudhya (Tachard 1686: 211-213, as quoted by Reid 1988:184-185). Cockfighting was already a popular male sport by the 16th century (Chumpagnern
2521), made famous by the legendary cockfight of King Naresuan. Bullfighting, with the bull pitted against another bull, not bull-against-matador as in Spain, is still a spectator sport in southeastern and southwestern Thailand. So are goat fights and sheep fights in southeastern Thailand and beetle fights in northern Thailand (Anderson 1998:128).

Dove cooing, however, assumed the form of a sport about 30 years ago. The Barred Ground Dove Association of Thailand, the organization of dove fanciers, initiated the dove-singing contest as an impetus for birdraisers to breed unique birds (Pornnantharat 2529). While dove-raisers in the past tended to be elderly men who raised them as pets, the evolution of the hobby into a sport has brought in new blood - dove enthusiasts of all ages and even a number of women. As dovecooing contests proliferated in southern Thailand, the stronghold of dove-raising, and spread to central Thailand, the north, and lately the northeast, regional and provincial level of dove-cooing contests grew into regular sport meets, especially during the dove mating season when the singing is at its best as male doves compete for the attention of the female dove. An indication of the popularity of the dove-cooing contest can be seen in the1987 provincial level contest in Bangkok that I attended, jointly organized by the Barred Ground Dove Association of Thailand and the Sport News Association of Thailand. The organizers had erected 200 dove poles on the contest ground, but the entries far exceeded their expectations. There were scores of disappointed dove owners who were not able to obtain hanging poles for their doves, a prerequisite for being included in the contest. 
The popularity of the dove-cooing contest became a mechanism for the economic growth of merchandise associated with doves. Besides the sale of doves, it fosters the sale of dove cages (and their paraphernalia from cage hangers, cloth cage covers, glass bead tassels, to food and water dishes), dove medicines, and dove song audio tapes. As with dove-raising in the past, it has enjoyed royal patronage. The largest and the most prestigious national dove-cooing contests are the three annual contests organized by the Barred Ground Dove Association of Thailand with royal trophies as the awards: the King's Cup Contest, the Prince's Cup Contest, and the Princess' Cup Contest. As many as 600-700 entries can be expected at these prestigious events. Her Royal Highness Princess Maha Chakri Sirindhorn often presides over the contest, especially the Princess' Cup Contest.

\section{Dove-cooing Contest as a Process}

Spectators at the dove-cooing contest are mostly male. Often referred to as a "birdsinging duel," the contest takes place during the months of October through May. The event is scheduled in the morning, from 6.00 A.M. to around12.00 A.M. when doves naturally sing over an extended length of time. The actual judging of the singing occurs in the last one or two hours, depending on the number of entries. The contest concludes in a day if the number of entries is small. With large numbers, the first day determines the winners of the first round who will then compete in the final round the second day. Competing doves are taken to the arena in beautiful cages, signifying the owner's love of his bird and often also the owner's socioeconomic status. M.R. Hataithani Jumbala, a member of the royal family and a dove fancier that I interviewed, has beautiful dove cages with cage hangers made of silver or brass inlaid with mother-of pearl, silver perch, and antique ceramic dishes for the dove feed and drinking water. At the arena, the dove cages are raised on poles, six meters tall and six meters apart.

Owners of the doves, not allowed into the arena where the dove poles are, stand around the edges quietly in order not to disturb the doves and to be able to hear the singing. Some arrive with binoculars to follow the performance of their bird or birds. More than one dove may be entered by a dove owner.

Doves in the contest are classified into 3 categories, based on the tonal characteristics of their cooing: low pitch, medium pitch, and high pitch. Each dove sings individualistic songs. The singing of each dove is listened to for one minute by two judges, each judge at a different interval. The melodic beauty of the cooing is evaluated and judged as a series of notes or movements: beginning movement, middle movement, and end movement. Points are given on: beginning note (20 points), resonance of the end note (30 points), duration of the end note (10 points), rhythm (20 points), and duration of the cooing (20 points). Occasionally, an exceptional songster is given 20 extra points for the overall beauty of his song composition (Wannaprasert 2528a: 124-126). A good songster sings over four notes, the more the better (Laosat 2520: 81). At least five to seven notes are desired in the contestants. Star singers can alternate their four-note sequence with a five-note sequence, and a six-note sequence, creating exceptional melodic beauty (Wannaprasert 2528b: 9), the possibility of gaining the extra 20 points for its 
song composition, and to be the winning songster.

Each dove has a name. The announcement of the winner gives the name of its owner, the dove's name, and the province both are from. Not every dove that is a good singer at home performs well at the contest, to the disappointment of his owner. I heard the complaint of a dove owner standing next to me in the contest I attended that his dove had been singing so well that morning. But for some reason it stopped singing when a judge came to rank its song. According to Wichai Tantisatjaphirat, a Chiang Mai dove-raiser and hobbyist, such a bird is judged as "having no fighting stamina in him" (personal communication, 1987).

\section{Of Doves and Men}

Why the dove-cooing contest enjoys such popularity in Thailand is an intriguing question, one that may perhaps be answered partly by the Thai value system itself and partly from the social interaction venues structured and offered through the raising of doves and entering them into the singing contests. Although a complete answer must include the active institutional support of the Barred Ground Dove Association of Thailand and the patronage of the Thai royal family, the underlying answers as to why it has attracted so many enthusiasts lie in the factors that make it attractive to them. Cockfighting, while enjoying continued participation of ardent adherents is, in comparison, not on the rise as a popular sport.

The first answer lies in the high value accorded to doves in Thai culture. According to the Thai taxonomic system of the animal world, birds as sad mii pig (animals with wings) are highly regarded because they descend from high above, like angels. Among the bird species, doves belong to a special class, distinctive by the fact that they are seed and grain eaters. Birds that do not feed on dead or living prey nor have to kill in order to survive are seen as belonging to the highest level of the bird order(Wannaprasert 2528b: 113). Despite the fact that the Thais themselves regularly eat meat, vegetarianism is held in high esteem, epitomizing a lofty spiritual attempt to strictly adhere to the basic Buddhist and moderate Muslim tenets against harming life. Secondly, while the cockfight is a blood sport, the razor spur on the leg of the cock can inflict "a ruptured chest, a gouged eye, a severed wing" and fatal throatslashing (Lapcharoensap 2005:165,167), the dove-cooing contest is not a contact sport and involves no bloodshed. Thirdly, the more humane profile of the doves is generally associated with the persona of the dove raiser/hobbyist. Dej Petkhaeg, a Thai Muslim villager on Koh Klang, a doveraising village I studied in southwestern Thailand, explicitly stated that those who do not raise doves tend to be less trustworthy and less sensitive than those who do.

The fourth explanation has to do with the special characteristics of the social network activated among the owners of dove contestants. Whereas dove-raising is an individualistic activity, the dove-cooing contest requires frequent and regular meetings of the participants. Years prior to the contest, the doves must be familiarized with the physical setup of the contest arena, punctuated by numerous dove poles and more doves than they are used to at home. The doves need to be trained not to suffer stage 
fright on the important contest day. To achieve all of this requires weekly rehearsal meets, including during the off-season. The gatherings have, in effect, drawn doveowners into one-on-one social interactions, meeting frequently, socializing, and sharing their knowledge about doves. "It's so much fun talking about doves," said one dove fancier (Wannaprasert 2528a:145). Most visibly, at the contest ground, this shared love and enthusiasm attract members of all socioeconomic classes, from aristocrats, governors, bankers, businessmen, university professors, elementary school teachers, and janitors, to farmers. It has had the effect of widening social fields and breaking down social barriers that exist in other contexts.

The dove-cooing sport appears to attract a certain group of Thai men with personalities that do not lend themselves to gregarious, rough-and-tumble, macho behavior. Dove raisers are, in all cases, bird lovers who find consolation, beauty, and peace of mind in the melody of the dove songs. A gathering of doveraisers becomes a social setting for the meeting of the like-minded and the like-temperament. As my interviews with dove-raisers indicate, these men, irrespective of their social class, end up visiting each other's home to talk about doves and to listen to each other's doves, thereby forming and expanding friendship bonding and social networking (Wichai Tantisatjapirat, personal communication, 1997) that can eventually expand into economic and political cooperation. Significantly, the activities surrounding the dove-cooing contest also create a chain of networking that crosscuts religious and ethnic boundaries, particularly in southern Thailand where dove owners are Buddhist Thai, Thai Muslim, as well as Chinese Thai. With the ethnic tension and fermenting
Thai Muslim irredentist political movements within the region, the weekly gatherings and contests in different locations in southern Thailand operate as a neutral ground and context for interactions that crosscut preexisting social ties, hierarchical class structure, and ethnic and religious boundaries. In regional contests, where dove owners come from different provinces, it also crosscuts governmental administrative territories.

Anthropologist Clifford Geertz, in his classic analysis of the Balinese cockfight (Geertz 1973: 434-435), analyzed the Balinese cockfight as "status gambling" where the "true cockfighter" bets his public self, his poise, his pride, and his masculinity - a greater stake than the risk taken by the "shallow cockfighter" whose sole motivation is winning money. Status and honor are, in a different way, present in the Thai dovecooing contest. But they reside in the ownership of the prize-winning dove, not in the betting. Metaphorically, a dove fancier expressed his view that to sell his favorite dove is like selling himself (Wannaparasert 2528a:4), a negation of self-respect and pride. Like farmer Loy in Golden Necklace who refuses to sell his dove for an ox-cart full of rice, a real-life villager, owner of a prizewinning dove in southern Thailand, is known to have turned down a Mercedes Benz a buyer offered in exchange for his bird. Beyond the individual level, a prized dove is also the pride of the village and the province. A Pattani dove owner declined a high offer for his award-winning dove, saying, "This dove belongs to the people of Pattani. If I sell him I'll be depriving Pattani people of the happiness of hearing him sing" (Wattanaprasert 2528b: 8). 


\section{The Singing Dove and the Image of the Self}

Thai animal sports, such as fishfights, cockfights, and bullfights, are male sports and the participants tend to be villagers or bluecollar workers. The major impetus for participating in these sports is betting. By contrast, the dove-cooing contest does not involve gambling. Neither owners nor spectators engage in betting. Monetary gain is fundamentally not part of the goal. Prizes are always in the form of trophies from dignitaries or small token awards. Neither is the committee organizing the contest in Thailand after big money. Sometimes the owner of a famous singing dove is invited to bring his dove to the tournament, paid for by the organizing committee, to add to the excitement of the event. Some invited dove owners are known to have graciously declined entering their famous dove into the contest in order to give another bird a winning chance. The judges at the contest, singing dove specialists themselves, do not seek payment for their job. The entry fee for each competing dove is minimal, as little as $\$ 1.00$ and up to a maximum of only about $\$ 8.00$, well within the range of affordability of dove owners. Neither are spectators to the event charged an admission fee. Most unique in the dove-cooing contest are the social causes the committee has built into the agenda. Proceeds from the event, besides providing lunch for the participating dove owners, are targeted to charity causes, such as scholarships for needy school children, support for a school lunch program in a poor village school, contribution to building a mosque, to victims of natural disasters, to the Red Cross, to Sai Jai Thai Foundation (Princess Sirindhorn's foundation)
(Pornnantharat 1986), or to a public project, such as purchasing walkie-talkies for the traffic police force of the province. Each year the committee tries to rotate the proceeds from the event to different worthwhile causes. The selection is at times made by the committee, at times based on the request that come in from the group requiring assistance.

The de-emphasis on profit making and the emphasis on providing social benefits as an organizational structure of the contest are, perhaps due to the particular mindset of the men who are attracted to dove-raising. In contrast to men who raise fighting cocks who tend to be nagleng (bold, often aggressive and defensive of their machismo) and who enjoy risk-taking and betting, dove raisers disassociate themselves from gambling. As a personality type, they tend to be both ascetic and aesthetic. They find contentment and aesthetic pleasure in caring for their birds and listening to their songs. I see dove-raising also as an activity that brings out in men nurturing behavior, generally associated with women, and child-rearing responsibilities. Dove hobbyists raise more than one dove because it is the competition among them that stimulates the flow of songs. The 1997 president of the Chiang Mai Barred Dove Association had around 200 doves. According to Wannaprasert $(2518: 7,10)$, to raise doves successfully, the raiser cannot be lazy. He has to get up early every morning, clean and put food and drinking water in the bird cage. He then has to raise the dove cages on individual dove poles or hang them on the eves of the house to let the doves spend the day in view of the trees and the sky - more or less like their natural habitat. Aloft on the poles, the doves are also far from aggravating noises, and bathing them in the sunlight is 
good for their health. In the summer heat, they need to be given a spray bath about once every two weeks. A dove fancier I interviewed gave his doves a shampoo every day. The dove's singing performance will improve through such constant care, nourishment, and proper doses of bird herbs and vitamins (Kananurak 2531:60).

To cultivate a bond between the dove and its raiser, some dove owners in the south take a dove cage into the rubber plantation with them. Some carry it to coffee shops or to a place with dove poles so that the dove is used to people and can have experience on the pole (Wannaprasert 2528a: 8). It takes as long as 9-12 years of constant care and 4-5 years on the poles for the wild doves to mature in their singing. Less time is needed for homebred doves, more familiar with human presence and the human habitat. At around two years old, home-bred doves can begin to be introduced into the singing contests (Wannaprasert 2528b:117). In personal terms, concrete cases of the loving care given to doves by dove hobbyists can be cited. In Koh Klang, Krabi where I conducted my field research, I once joked to a young adolescent girl who was part of my adolescent study group that her family must eat a lot of somtum (green papaya salad), having so many papaya trees around the house. She laughed, saying that her father put in papaya trees for his more than ten pet doves that love ripe papaya. Wannaprasert cited cases of wives teasing their husbands for loving their favorite doves more than their wives. Tongue-in-cheek, Wannaprasert advocates the hobby for husbands. A husband who raises doves always returns home after work to take care of his doves instead of dallying elsewhere or getting involved in negative activities (Wannaprasert 2528b: 129, Laosat 2520: 79). The hobby directly benefits his wife and his children who can count on his company at home, Wannaprasert says.

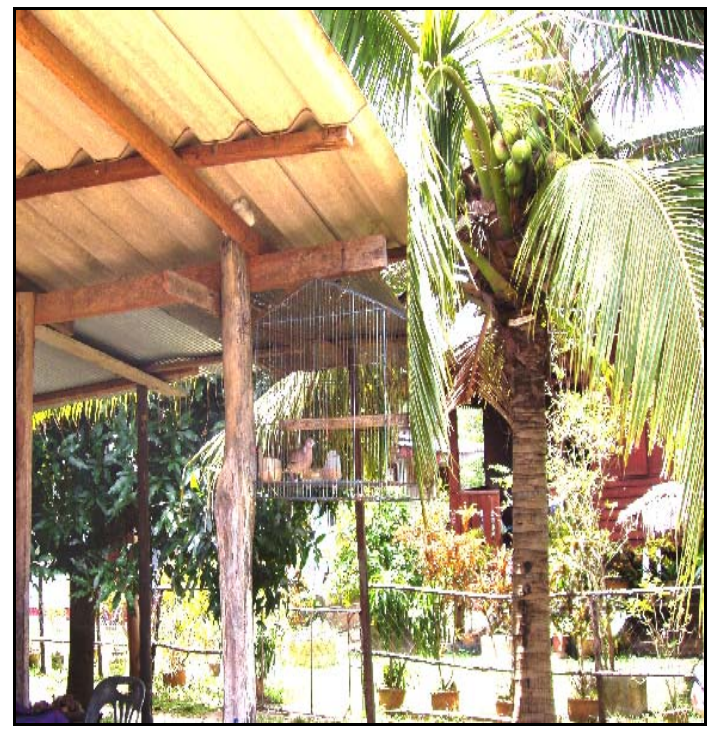

Many dove hobbyists raise other birds as well, some birds for their colorful plumage, others, for example myna birds and parrots, because they can be taught to speak. Birds that have been raised for their melodious singing include the smaller, nok grong hua juke, the redwhiskered bulbul (Pycnonotus jocosus spp.), adorned with a pointed crest on its head. The red-whiskered bulbul singing contest is enjoying growing popularity in southern Thailand, especially in Krabi where I attended a singing event. It is a more recent sport relative to the dove-cooing contest, but it attests to the continual development and popularity of bird-singing contests in Thailand. In Thai culture ascetic and the aesthetic qualities have always been valued, the ascetic as exemplified by the Buddha and Buddhist monks, the aesthetic artistry by the high esteem accorded to artists and poet princes and 
kings, such as the poet Sunthorn Phu, Prince Thammathibet, and King Vajiravudh. Giving to charity causes has also been articulated as "making merit," the concept shared by Buddhist Thai, Buddhist Chinese, and Thai Muslims alike. A dove hobbyist is thus given a respectable, positive image.

The positiveness of the image has been given an added dimension in the metaphorical association of birds with manhood. The Thai word for "bird" is "nok" which is also a euphemism for the male reproductive organ. Dove as a metaphor for manhood has been appropriated by the Planned Parenthood Program of the Ministry of Health, seen in a number of posters produced and distributed to hospitals and rural health clinics. Capitalizing on the familiar euphemism, the poster attempts to nullify the myth of male impotence resulting from vasectomy. The words in a poster with a picture of a dove flying say, "The dove still flies high after the vasectomy." Thus a virile man, a new symbolic meaning, has been added to the existing meanings of men the ascetic, men the aesthetic, and a social being with a social conscience and appreciation of beauty in nature.

\section{Transnationalism: A New Development}

Within the last decade, the sport has taken on an additional dimension of transnationalism, a process by which people create economic connections and mobility across space (Ong 1999: 4) and maintain multiple social relations across national boundaries (Basch, Glick Schiller, and Szanton Blanc 1994). In the last decade the dove-cooing contest has evolved into a Southeast Asian international sport. The First ASEAN Zebra Dove-cooing
Contest, was organized in March, 1985, in Yala, southeastern Thailand. It had dove songsters from Malaysia, Singapore, and Indonesia. One of the stated goals of the organizing committee was to foster relations among the peoples of neighboring ASEAN countries, thus making the dove-cooing contest a milieu for fostering positive human relations across national boundaries. About 600 doves took part in the contest and 100 awards were given out (The Bangkok Post 1985). The second ASEAN Dove-cooing Contest, held in Singapore, had 420 entries (Stephens 2000). Thai singing doves have been taken to tournaments in Malaysia, Singapore, and Indonesia. But more doves from Malaysia than from Indonesia have come to compete in the singing meets in Thailand (Wannaprasert 2528b: 5). Owing to its geographic location and its long history of dove-raising, southeastern Thailand, particularly Pattani, has become the premier market for the best singing doves and dove paraphernalia, nationally and internationally, although wild doves from Krabi, southwestern Thailand, have also gained fame. As soon as a dove wins a major singing trophy, a high offer, unsolicited, comes from interested dove enthusiasts. Sometimes a buyer is successful and returns home the proud owner of the bird, hoping that in the next singing contest, he will be known as the owner of the winning songster. A trophy winner can command as much as $\$ 68,000$, the price paid in 1995 by a Singaporean buyer (Gampell 2000). A Malaysian millionaire bought the winner of the 2004 Yala contest for 1.7 million baht (around \$44,500) (New Straits Times 2004).

The year 2005 marks the twentieth anniversary of the ASEAN Zebra Dove-cooing Contest as an international sport. Taking place in Yala in 
March with more than 1,400 entries, it had also the participation of another Southeast Asian country, Brunei. A concomitant development from the ASEAN contest is the transnational economics of dove-raising and dove-selling. At least two Singaporeans, Mohammed Samshuddin (a Singaporean Muslim hardware business owner) and James Lim (a Chinese Singaporean owner of a ship repair business), have been known to operate dove farms for several years overseas - in Pattani, southeastern Thailand (Stephens 2000). It appears that the increasing temptation of profit-making through economic transnationalism, the high-price trading of champion dove across national borders, has become a new challenge and threat to the spirit of dove-raising and dove-cooing contests as originally conceived and nourished by dove fanciers.

Not much known outside Thailand, Malaysia, Singapore, Indonesia, and Brunei, the dovecooing contest has multiple structural and ideational dynamics. Not simply a folk sport, an animal sport in and of itself, it is about the man, the dove fancier. But it also transcends the individual. In its national, societal context, its organization is more socially and ethnically diverse, more socially aware, and more engaged in the needs of the community. It facilitates boundary-crossings in ways that cockfighting cannot accomplish. Its Southeast Asian transnational sports profile has put the contest and the Thai singing doves on the region's cultural page beyond Thailand and has made the prize-winning songsters a most expensive Thai commodity and economic export. Even more than cockfighting, the dove-cooing contest is a "deeper play" in the Geertzian sense (Geertz 1973) in that it has deeper meanings beyond the surface meaning of the competition itself.

\section{References}

Anderson, Wanni W. 1989. Sport in Thailand. In Sport in Asia and Africa: A Comparative Handbook, Eric A.Wagner ed., pp.121-146. New York: Greenwood Press.

Basch, Linda, Nina Glick Schiller and Cristina Szanton Blanc. 1994. Nations Unbound: Transnational Projects, Postcolonial Predicaments, and Deterritorialized Nation-State. Langhorne: Gordon and Breach.

Gampell, Jennifer. 2000. Detour: 'Dove Tales'. Time Asia, October.

Geertz, Clifford. 1973. 'Deep Play: Notes on the Balinese Cockfight'. In The Interpretation of Cultures, pp.412453, New York: Basic Books.

Lapcharoensap, Rattanawut. 2005. Sight'seeing. New York: Grove Press.

Lekagul, Boonsong and Edward W. Cronon Jr. 1974. Bird Guide of Thailand. $2^{\text {nd }}$ edition, Bangkok: Kurusapa Ladprao Press.

New Straits Times. 2004. Fewer Birds in Annual Dove Cooing Contest, August 23. 
Ong, Aihwah. 1999. Flexible Citizenship: The Cultural Logics of Transnationality. Durham: Duke University Press.

Pornnantharat, Sayant. 1986. 'Cooing Dove Contest in Narathiwas', The Bangkok Post, September 23.

Reid, Anthony.1988. 'Southeast Asian in the Age of Commerce 1450-1680' Vol I: The Lands below the Winds. New Haven: Yale University Press.

Stephens, Jacintha. 2000. No Place for Cheep Trills: Inside the Costly World of Songbird Breeding. Asiaweek 29(4).

Tachard, Guy 1686. A Relation of the Voyage to Siam Performed by Six Jesuits. English translation. London: A. Churchill. Reprinted Bangkok: White Lotus Press, 1981.

The Bangkok Post. 1986. Dove -cooing Contest to Be Held in Yala, January 30.

\section{In Thai}

Chumpangern, Sombat. 2521. Thai Sports. Bangkok: Suwiriyasan.

Kananurak, Mullika. 2531. Raising Javanese Singing Doves as a Hobby. Bangkok: Odeon Store Press.

Laosat, Orrayan. 2526. The Sounds of Javanese Doves. Rusamilae, 7(1): 79-80.
Phumetaworn, Nimit. 2525. Soi Tong

(Golden Necklace). Bangkok:

Bannakit Press.

Wannaprasert, Prakob. 2528a. Javanese Dove: a Complete Text. Bangkok: Buraphasan Press. .2528b. Tactical Training and Taking Care of Merbok. Bangkok: Buraphasan. 